Article

\title{
The Effect of Rainfall on Economic Growth in Thailand: A Blessing for Poor Provinces
}

\author{
Siriklao Sangkhaphan ${ }^{1}$ and Yang Shu ${ }^{2, *}$ \\ 1 School of Economics, Huazhong University of Science and Technology, 1037 Luoyu Road, Wuhan 430074, \\ China; siriklao@yahoo.com \\ 2 School of Economics and Trade, Hunan University, 2 Lushan S Rd, Changsha 410008, China \\ * Correspondence: shuyang@hnu.edu.cn; Tel.: +86-181-4068-4099
}

Received: 5 November 2019; Accepted: 2 December 2019; Published: 18 December 2019

\begin{abstract}
Rainfall is related to economic growth and generally has beneficial impacts on dry and poor areas that are mostly dependent on rainfed agriculture. Thailand is a service-based, upper middle-income country with a tropical climate although rainfall varies regionally. The volume of precipitation in the northern and northeastern regions is rather low while the southern region has the highest rainfall due to its narrow topography running north-south bordering the Andaman Sea to the west and the Gulf of Thailand to the east. The present study explored the effect of rainfall on the growth of the gross provincial product (GPP) by economic sector and subsector using provincial-level panel data from 1995 to 2015. The feasible generalised least squares (FGLS) estimator with fixed effect was used in the regression models. We found that the main impacts of the weather occurred through rainfall and reduced GPP growth at the national level. For the sector level, the results showed that rainfall had a significant negative impact on the agricultural and service sectors while it had a positive but not significant impact on the industrial sector. However, rainfall remains vital in poor regions although it could be detrimental to certain subsectors in those regions. The results confirmed that the positive effects of rainfall mostly affected the economies of poor provinces and suggested that average rainfall could be the key climate effect on economic growth in Thailand.
\end{abstract}

Keywords: rainfall; economic growth; economic sector; economic subsector; panel data; the FGLS estimator; JEL Classification: O44; O47; Q54

\section{Introduction}

Policymakers are becoming increasingly concerned about the economic effects of climate change (Brown et al. 2011). There is now sturdy agreement among scientists that anthropogenic emissions are already underway due to the burning of fossil fuels and releasing of carbon dioxide as well as other greenhouse gases into the atmosphere (The Intergovernmental Panel on Climate Change (IPCC) 2007b). The idea that the climate may have substantial economic impacts is not a new concept with such ideas being found in the writing of the ancient Greeks and in Ibn Khaldun's 14th-century Muqaddimah (Gates 1967). For centuries, thinkers have considered whether and how climatic conditions; such as, temperature, rainfall, and violent storms influence the nature of societies and economic performance (Carleton and Hsiang 2016). This is consistent with Berlemann and Wenzel (2018) who proposed that economic sectors are driven by the phenomenon of climate change resulting in the rediscovery that climate conditions are potential determinants of economic activity. Moreover, temperature and rainfall are two climatic variables typically represented in economic growth models, but there is greater focus on temperature. The existing literature has also suggested that temperature increases negatively affected economic growth (Akram 2012; Dell et al. 2012; Lanzafame 2014; Sequeira et al. 2018), whereas 
rainfall could have both positive (Brown et al. 2013; Odusola and Abidoye 2015) and negative effects on gross domestic product (GDP) growth (Dell et al. 2012; Tebaldi and Beaudin 2016).

The impact of climate and the role of water security on economic growth are subjects of increased interest (Brown et al. 2013). Evidence suggests that climate change affects precipitation patterns (Dore 2005) with climate change, therefore potentially affecting economic growth through rainfall variability (Ali 2012). Nonetheless, few studies have examined and explored the connection between rainfall and economic growth with most of the existing research having been conducted in African countries (Ali 2012; Barrios et al. 2010; Berlemann and Wenzel 2018; Cabral 2014; Hissler 2010; Miguel and Satyanath 2011; Richardson 2007); such as in Sub-Saharan Africa where rainfed agriculture is dominant (Borgomeo et al. 2018).

Thailand has a service-based economy and is an upper-middle-income country (World Bank 2011). However, the majority of existing studies have investigated the economic impact of rainfall on poor, agricultural-based economies (Gadgil and Gadgil 2006; Gilmont et al. 2018), which differ greatly from Thailand. Moreover, several researchers have investigated African countries facing arid and semi-arid conditions characterised by erratic and seasonally low rainfall of less than $700 \mathrm{~mm}$ per year (Wild 2015). In contrast, Thailand is situated in the tropics with an annual rainfall of approximately $1400 \mathrm{~mm}$ (Richardson 2007). Thus, the current study differed from the existing literature concerning the country's income level, economic characteristics, and volume of rainfall. Our main assumption was that rainfall may influence the Thai economy differently compared to agriculture-based economies that have been previously explored in depth in the available literature.

Despite the literature's focus on the effects of rainfall on poor countries dependent on the agricultural sector, rainfall can also affect other sectors. According to Becken and Wilson (2013), extreme rainfall and drought influenced the profitability and popularity of the tourism sector in New Zealand. In addition, countries that are reliant on hydroelectricity or other types of water energy production are heavily dependent on adequate annual rainfall (Solaun and Cerdá 2017). In terms of economic activity, Jones and Olken (2010), who considered the losses in industrial output by examining a global sample of trade data, found that for each $1^{\circ} \mathrm{C}$ of warming, poor countries faced an average $2.4 \%$ decline in exports. However, there has not yet been a robust clarification of the effect of average precipitation.

The purpose of this study was to investigate how rainfall affected Thai economic growth. Our first objective involved estimating the impact of rainfall on the aggregate GDP growth at the provincial level, whereas the second objective was to conduct a detailed examination of individual economic sectors such as, agriculture, industry, and services. We decided to investigate these three sectors since there was no reason to assume that annual rainfall would affect them in a similar manner. Moreover, additional evidence was provided to show that rainfall affected these sectors and their subsectors. To the best of our knowledge, this research has never been undertaken in Thailand.

Weather estimates have long been used in statistical models as explanatory variables (Auffhammer et al. 2013). Weather works similar to a "natural experiment" since it has external causes and can have seemingly random effects on economic activities, while we are able to recognise the statistical causal effect of one weather variable on economic results (Angrist and Krueger 2001). In the present study, rainfall was taken as a variable of interest while temperature was used as the control variable. The fundamental assumption was based on the premise that economies could be influenced by rainfall. This was consistent with Brown et al. (2013) who suggested that precipitation extremes had been the key climate determinant of historical GDP growth. An economic growth model was developed subsequently to incorporate rainfall as a climatic variable in the production function (Ali 2012; Brown et al. 2013; Henseler and Schumacher 2019). Hence, in the case of Thailand, the feasible generalised least squares (FGLS) estimator was used to analyse panel data across the country's 76 provinces from 1995 to 2015.

Three major conclusions were drawn from the study. First, at the national level, rainfall had a significantly negative impact on the growth of the gross provincial product (GPP) while temperature 
had a positive but not significant impact. This result implied that rainfall was the key climatic variable. In addition, rainfall was crucial for Thailand's poorer regions. Second, the agricultural sector was the most vulnerable sector to rainfall while the service sector was the second most vulnerable. However, the industrial sector was positively but not significantly affected by rainfall. Finally, at the subsector level, the results showed that rainfall was beneficial to mining, hotels and restaurants while the agricultural, public administration, defence, and health subsectors were negatively affected by rainfall. Overall, the results displayed that rainfall had a largely negative affect on Thai economic activities, thus implying that the Thai economy was sensitive to rainfall.

These results contributed to the existing literature by clarifying how precipitation affects aggregate economic growth and in certain economic sectors. Furthermore, the findings provided important insights into which economic subsectors should be supported by the government, especially during predictable rainy seasons, as well as determining which areas should receive improved water management, particularly poor regions. Finally, the findings may motivate similar research in other developing countries in the region, and provide a host of new results about how precipitation and other weather aspects affect the economy.

The present paper is structured as follows: The first section begins with the introduction. The next section reviews the existing literature concerning how precipitation could affect economic growth. This is followed by the theoretical framework and the empirical model using data sources and a summary of the variables. The results and discussion are presented in Section 4 followed by the conclusion in Section 5.

\section{Literature Review}

Recent studies have sought to explore how rainfall impacts economic growth, although this is a rather new perspective. Most of the existing literature has focused on the impact of climate change on economic growth by considering temperature and rainfall as climatic variables. Moreover, mostly discussions of the topic have focussed on the expected increase in average global temperatures. For example, Dell et al. (2009) and Horowitz (2009) suggested that higher temperatures would reduce income, particularly in lesser developed countries (Dell et al. 2012).

A few previous studies focussed only on rainfall as a climatic variable (Ali 2012; Barrios et al. 2010; Cabral 2014; Gilmont et al. 2018; Hissler 2010; Miguel and Satyanath 2011; Richardson 2007; Tebaldi and Beaudin 2016). However, climate change affects precipitation patterns (Berlemann and Wenzel 2018); thus, climate change may impact economic growth as a result of the variability of rainfall (Ali 2012). Therefore, rainfall can be represented as a climate variable to study the aspect of climate change. Furthermore, this was consistent with Brown et al. (2013), who found that extreme rainfall was the key variable of climate while temperature was found to have little significance on economic growth. Hence, the present study focussed on the rainfall variable in order to contribute new evidence about a tropical country like Thailand. The core assumption was that rainfall affected economic growth, which was consistent with Brown et al. (2013). An alternative assumption stated that rainfall may affect economic sectors differently. These two assumptions formed the basic perspective of this study.

Rainfall can both positively and negatively affect economic growth; in addition, most previous studies have focussed on countries with rainfed agriculture at the national level. In particular, African countries, which depend mainly on the agriculture sector, were found to have rainfall positively affecting economic growth. Miguel and Satyanath (2011) estimated the relationship between rainfall, economic growth, and civil unrest and conflict in Sub-Saharan African (SSA) countries. Their results showed that rainfall levels and rainfall growth had a positive impact on the GDP per capita growth. They also addressed political as well as economic issues finding that adverse economic shocks resulted in civic violence. Additionally, Odusola and Abidoye (2015) examined the impact of rainfall variability on economic growth in African countries and found that a $1 \%$ increase in rainfall resulted in a $6.6 \%$ increase in economic growth. Lanzafame (2014) also determined that the aggregated effects of rainfall positively influenced economic growth in Africa. Moreover, Sequeira et al. (2018) confirmed the 
positive effect of higher precipitation in poor countries with either hot or temperate climates. Finally, Phatcharopaswatanagul (2018) showed that rainfall had a positive impact on cassava yields in Thailand.

Secondly, a lack of rainfall has been shown to be economically detrimental. For instance, Berlemann and Wenzel (2015) showed that droughts can cause substantial negative long-term growth in both rich and poor countries. Similarly, Dell et al. (2012) concluded that the lack of precipitation negatively affected economic growth in poor countries. Furthermore, Richardson (2007) provided evidence suggesting that erratic and unpredictable rainfall as well as gross governmental mismanagement created economic difficulties in Zimbabwe. Ali (2012) also investigated the effects of rainfall on Ethiopia's highly rainfed-dependent economy demonstrating that the extent of the adverse impact of rainfall variability on economic growth largely depended upon the rate of expansion of the amplitude of rainfall variability and the frequency of extreme events.

Likewise, several studies have compared the impact of rainfall surplus and deficiency on economic growth, particularly in relation to the agricultural sector. Gadgil and Gadgil (2006) observed that rainfall deficiency had a greater magnitude of impact on the GDP compared to surplus rainfall in India. Yet Lertamphainont and Sparrow (2016) noted that crop income fell sharply due to rainfall extremes from either floods or droughts. They suggested that in Thailand, excessive rainfall resulted in income smoothing through asset transactions and off-farm employment changes, but the same was not found for drought events. Additionally, Tebaldi and Beaudin (2016) conducted an in-depth study of seasonal rainfall and found that spring droughts and summer floods severely affected northeastern Brazil, a region that has long been the country's poorest region. Finally, Brown et al. (2013) investigated precipitation extremes in terms of drought and flood indices across 133 countries. The drought index was found to be associated with a highly significant negative influence on GDP growth, and while the flood index was also associated with a negative influence on GDP growth, this relationship had a reduced magnitude. Moreover, flooding was found to negatively impact industrial sectors. These findings indicate that historical GDP growth has been affected by precipitation extremes, rather than by temperature as has been previously reported and suggested by many researchers (Akram 2012; Alagidede et al. 2015; Dell et al. 2012; Henseler and Schumacher 2019; Lanzafame 2014; Sequeira et al. 2018; Zeb 2013).

Finally, few in-depth studies have addressed how rainfall influences the economic sector. Akram (2012) studied Asian countries and found that while economic growth was negatively affected by population growth, it was positively affected by precipitation. Furthermore, he determined that rainfall had a significant positive impact on the agricultural and manufacturing sectors, but it had no influence on the service sector. Loayza et al. (2012) examined how natural disasters affected economic sector growth, concluding that disasters had the potential to affect economic growth, but this effect was not always negative. For example, moderate flooding could generate positive economic growth in the agricultural, industrial, and service sectors. Flooding could also positively affect the agricultural sector since floods were often localised and concentrated in small areas, thus meaning that floodwater could be used as a plentiful annual water supply for irrigation which would improve agricultural productivity. Moreover, whenever nations used hydroelectricity or other forms of energy production that utilised water as a secondary input, rainfall would have an influence on the energy sector and floods could improve industrial output (Solaun and Cerdá 2017). Additionally, the service sector is promoted by flooding because this area of the economy has strong links with both agriculture and industry, particularly in developing countries. Lastly, Hissler (2010) found that rainfall deviation influenced agriculture more than urban growth.

The existing literature has largely considered the relationship between rainfall and economic growth from a macroscale using national data from many different countries. There is a generally positive relationship between rainfall and economic growth meaning that higher rainfall mostly stimulates economic growth, whereas reduction in the amount of rainfall has an adverse impact on economic growth. Consequently, rainfall variability can both improve and affect economic growth, particularly in poor and arid countries reliant on agriculture. Furthermore, while a few previous studies 
have examined the effect of rainfall on economic growth at the sector level (agricultural, industrial, and service), they have ignored the subsector levels. Therefore, the present study was conducted to present an in-depth examination of how both the economic sector and the related subsector levels were affected and influenced by precipitation.

\section{Methodology}

Weather has the potential to both improve and degrade a country's economic development. Based on a simple production model, climate is assumed to influence productivity. Rainfall was added directly to the model as a climate variable and as an additional factor to explain economic performance (Ali 2012; Berlemann and Wenzel 2018; Brown et al. 2013; Tebaldi and Beaudin 2016). Our primary goal was to investigate whether rainfall affected national economic growth.

\subsection{Theoretical Framework}

We attempted to explain the link of economic growth to weather conditions based on a simple production function. Henseler and Henseler and Schumacher (2019) provided evidence of a wider perspective by assuming that the GDP was a function of the climatic variables. Proxied by temperature and precipitation, climatic conditions could affect each of the three components of production, which are capital, labour and total factor productivity (TFP), in a similar way to GDP. These three components had a positive impact on the GDP, on which economists concurred in general. In knowing which components of production impacted at the macro level would then help policymakers to effectively support and evaluate the climate change policy. For instance, if temperature was to affect capital dominantly, then it would seem logical to direct policy towards disaster prevention and adaptation (Fankhauser and Tol 2005). This evidence was consistent with Ali (2012) who focused on the rainfall variable instead and assumed that rainfall affected growth by directly impacting the productivity of capital. Moreover, if temperature were to greatly affect the TFP, then subsidies to research and development (R\&D) would prove beneficial (Nordhaus 2010). On the other hand if, instead, temperature was to reduce labour; e.g., through the dissemination of disease, then climate policy would need to emphasise health issues (Mariani et al. 2010).

In addition, the theoretical connection between economic growth and climate change could be exhibited through macroeconomic and microeconomic dimensions (Abidoye and Odusola 2015). For the macroeconomic aspect, the influence would be on the level output; such as, agricultural yields and economy's ability to grow. For instance, by affecting investments or institutions that influence productivity growth could be two areas that would need to be the most emphasised (Dell et al. 2012). From the analysis of the microeconomic dimension, the linkage would contain an array of factors; such as, physical and cognitive labour productivity, conflict, health and democratisation; all of which could have economy-wide implications (Burke and Leigh 2010; Gallup et al. 1999; The Intergovernmental Panel on Climate Change (IPCC) 2007a). For example, increased temperature could lead to political instability, which in turn may obstruct factor accumulation and productivity growth.

Therefore, the present study conducted the theoretical framework from these two research studies (Abidoye and Odusola 2015; Henseler and Schumacher 2019) to explain the link between economic growth and climatic variables with the variable of interest being rainfall.

\subsection{Empirical Framework}

The empirical framework of this study was in accordance with Dell et al. (2014). To understand the effect of climate on economic outcomes, they provided the ideal function to determine the unknown functional relationship. This is exhibited in Equation (1):

$$
y=f(C, X)
$$


which shows the relations vectors of the climate variables $(C)$ and other variables $(X)$ to the outcomes, y. $C$ may include temperature, precipitation, and extreme weather. The outcomes of interest would include national income, agricultural output, industrial output, labour productivity, political stability, energy use, health, and migration, among others. $X$ would include any characteristics correlating with $C$, which affect the outcomes of interest possibly by conditioning the climate response.

\subsection{Empirical Model}

Consistent with the description of Equation (1), the empirical model specified the use of the rainfall variable introduced as an added growth model determinant. In this analysis, the FGLS with the fixed effect approach was used to estimate the panel data.

The empirical model was expressed as Equation (2):

$$
\Delta y_{i, t}=\gamma_{1} \text { pre }_{i, t}+\gamma_{2} \text { temp }_{i, t}+\gamma_{3} \text { pop }_{i, t}+\alpha_{i}+a_{t}+\varepsilon_{i, t}
$$

where $\Delta y_{i, t}$ represents the GPP per capita growth rate in the province $i$ at the time $t ; y$ is the natural logarithm of the GPP per capita, pre $i, t$ is the average annual precipitation, temp $p_{i, t}$ is the average annual temperature, pop $_{i, t}$ is the population growth rate, $\alpha_{i}$ is the province fixed effect, $a_{t}$ is the time fixed effect, and $\varepsilon_{i, t}$ is the unexplained residual. In addition, Equation (2) considered the interactions between the weather variables and province characteristics based on Thailand's poorer regions.

To the difference between the poor and rich sample, we utilised a dummy province, which had the value of 1 if the gross regional product (GRP) per capita in its province was below or equal to the 25th percentile in its previous year, here was in 2015 and a zero otherwise. The research found that the GRP of the northeastern region (19 provinces) was below the 25 th percentile, and the northern region (17 provinces) was equal to the 25 th percentile. Therefore, the provinces in these two areas represented a poor dummy.

For a robustness check, the present study added temperature to the estimated model since the rainfall variable may correlate with temperature (Auffhammer et al. 2013). First, only temperature was used as a control variable to avoid the problem of over-controlling (Dell et al. 2014), which appeared to be a reasonable estimation. However, the core set of the control variables used in the growth regression consisted of only a few variables, which could be directly derived from the theoretical economic growth models; such as, the initial GDP per capita level, the saving rate, and population growth (Berlemann and Wenzel 2018). Moreover, numerous studies have used population growth as a control variable in the field of climate change (Akram 2012; Odusola and Abidoye 2015; Zeb 2013). When considering the econometric perspective, extra variables were added to the regression model but were uncorrelated with the explanatory variable of interest, which was often a key policy variable (Wooldridge 2015). This evidence assumed that rainfall was not related to population growth. Therefore, this research used population growth as both a control variable and as a key policy variable.

\subsection{Data Type and Sources}

This section describes the data sources and procedures used to aggregate the data at the provincial level and provides some descriptive statistics for the main variables (refer to Table 1). The empirical study relied on panel datasets collected from different Thai government organisations between 1995 and 2015 (a period of 21 years) across 76 provinces nationwide.

- Weather station data included ground station data collected by the Thai Meteorological Department (2016). The dataset incorporated daily data taken from 129 Thai weather stations between 1995 and 2015. The average annual rainfall (millimetres) and annual temperature (Celsius) were used and calculated using average monthly data. Temperature was included here as a robustness check.

- Provincial level GDP data was taken from real GDP by province (also known as gross provincial product [GPP] in Thailand, using chain volume measures against the reference year 2002, which was 
collected by the Office of the National Economic and Social Development Board of Thailand (2017). This dataset was reported in an annual series in Thai baht. This research studied the economic sector level in depth by classifying 16 economic activities into three sectors, which were agriculture, industry and service (refer to Table A4). The research used real GPP per capita growth for all economic activities.

- Population data was collected from the Department of Provincial Administration (2018). The dataset was reported in an annual series. The research used the population growth rate in an annual series.

Table 1. Summary statistics of the variables.

\begin{tabular}{cccccc}
\hline Variable & Obs & Mean & Std. Dev. & Min & Max \\
\hline Gross provincial product (GPP) per capita growth & 1596 & 0.023 & 0.067 & -0.39 & 0.43 \\
Agriculture per capita growth & 1596 & 0.013 & 0.110 & -1.65 & 0.86 \\
Industry per capita growth & 1596 & 0.020 & 0.139 & -0.96 & 0.80 \\
Service per capita growth & 1596 & 0.025 & 0.060 & -0.32 & 0.59 \\
Farming per capita growth & 1596 & 0.014 & 0.108 & -1.67 & 0.57 \\
Mining per capita growth & 1596 & 0.027 & 0.368 & -2.32 & 2.58 \\
Hotel per capita growth & 1596 & 0.048 & 0.219 & -1.35 & 1.45 \\
Public per capita growth & 1596 & 0.009 & 0.154 & -0.88 & 0.85 \\
Health per capita growth & 1596 & 0.051 & 0.120 & -1.72 & 1.12 \\
Population growth rate & 1596 & 0.006 & 0.012 & -0.06 & 0.15 \\
Annual average rainfall (100 mm/year) & 1596 & 1.295 & 0.665 & 0.29 & 5.39 \\
Annual average temperature $\left({ }^{\circ} \mathrm{C}\right)$ & 1596 & 27.479 & 1.045 & 21.06 & 29.60 \\
\hline
\end{tabular}

Note: All growth variables are in natural logs, except population growth rate.

\section{Results and Discussion}

This section presents the results and discusses the positive and negative effects of rainfall on GPP growth. In general, the panel unit root test is not conducted when a cross-sectional unit is greater than a time-series unit; however, the present study performed this test because the macroeconomic variables were often found to be non-stationary (Alagidede et al. 2015), so the cross-sectionally augmented Im-Pesaran-Shin (CIPS) panel unit root test was conducted to determine their order of integration. The test results showed that all the variables were statistically significant suggesting that there was no unit root in the panel data. This meant that all the variables could be estimated for the panel data (refer to Appendix A.1).

Next, panel heteroscedasticity tests were undertaken to investigate the stationary variance of the error term. The nine models were examined by applying the Breusch-Pagan/Cook-Weisberg test. Three models showed homoscedasticity while the other six models rejected the null hypothesis and exhibited heteroscedasticity (refer to Appendix A.2). To overcome this issue, we used the FGLS estimator.

These two tests were appropriate for checking the variables and all the models. In the final step, we estimated the model using effective techniques based on the two-estimation result.

\subsection{Main Economic Growth Results}

Table 2 examines how precipitation affects the GPP per capita growth. Table 2, Column 1 shows a negative statistically significant relationship between precipitation and growth on average across the 76 provinces. In Column 2, we interacted precipitation with a dummy for a province being "poor", which was defined as the region with the lowest GRP, with the first and the second regions being ranked; namely, the Northeast and North, respectively (Office of the National Economic and Social Development Board of Thailand 2015). The interaction coefficient between the "poor" dummy and precipitation was positive and strongly statistically significant indicating substantial heterogeneity between the poor and rich regions. This evidence indicated that precipitation tended to affect poor 
regions greater than rich areas. According to the coefficient value, the effect of a $100 \mathrm{~mm}$ variation in precipitation had an influence on the economic growth in poor regions greater than in rich areas by $3.37 \%$. This implied that precipitation in the poor areas had more importance than rich areas in Thailand.

Table 2. Main economic growth results. Sample: 76 provinces (1995-2015).

\begin{tabular}{|c|c|c|c|c|c|}
\hline \multirow{2}{*}{$\begin{array}{c}\text { Dependent Variable Is the } \\
\text { Annual Growth Rate }\end{array}$} & \multicolumn{4}{|c|}{ Feasible Generalised Least Squares (FGLS) } & \multirow{2}{*}{$\begin{array}{l}\text { Ordinary Least } \\
\text { Squares (OLS) } \\
(5)\end{array}$} \\
\hline & (1) & (2) & (3) & (4) & \\
\hline Precipitation (100 mm/year) & $\begin{array}{l}-0.0120 * \\
(0.0063)\end{array}$ & $\begin{array}{c}-0.0238^{* * *} \\
(0.0076)\end{array}$ & $\begin{array}{c}-0.0231^{* * *} \\
(0.0077)\end{array}$ & $\begin{array}{c}-0.0234^{* * *} \\
(0.0077)\end{array}$ & $\begin{array}{c}-0.0234^{* *} \\
(0.0090)\end{array}$ \\
\hline $\begin{array}{l}\text { Precipitation interact with ... } \\
\text { Poor province dummy }\end{array}$ & & $\begin{array}{l}0.0337^{* * *} \\
(0.0121)\end{array}$ & $\begin{array}{l}0.0322 * * * \\
(0.0125)\end{array}$ & $\begin{array}{c}0.0322 * * * \\
(0.0125)\end{array}$ & $\begin{array}{l}0.0322 * * \\
(0.0130)\end{array}$ \\
\hline Temperature (Celsius) & & & $\begin{array}{l}0.00383 \\
(0.0072)\end{array}$ & $\begin{array}{l}0.00321 \\
(0.0072)\end{array}$ & $\begin{array}{l}0.00321 \\
(0.0081)\end{array}$ \\
\hline $\begin{array}{c}\text { Temperature interact with ... } \\
\text { Poor province dummy }\end{array}$ & & & $\begin{array}{c}-0.00321 \\
(0.0070)\end{array}$ & $\begin{array}{c}-0.00247 \\
(0.0070)\end{array}$ & $\begin{array}{c}-0.00247 \\
(0.0079)\end{array}$ \\
\hline Population growth & & & & $\begin{array}{l}-0.421^{* *} \\
(0.1866)\end{array}$ & $\begin{array}{l}-0.421 * * \\
(0.2109)\end{array}$ \\
\hline Constant & $\begin{array}{c}0.000445 \\
(0.0153)\end{array}$ & $\begin{array}{c}0.0320 \\
(0.0187)\end{array}$ & $\begin{array}{l}-0.0731 \\
(0.1107)\end{array}$ & $\begin{array}{c}0.0443 \\
(0.1069)\end{array}$ & $\begin{array}{c}0.0443 \\
(0.0778)\end{array}$ \\
\hline Observations & 1596 & 1596 & 1596 & 1596 & 1596 \\
\hline $\begin{array}{l}\text { Log likelihood } \\
R^{2}\end{array}$ & 2188.786 & 2192.647 & 2192.790 & 2195.334 & 0.2706 \\
\hline
\end{tabular}

Notes: 1. Standard errors in parentheses; 2. Time and provincial fixed effects were included (coefficient not reported); 3. * Significant at $10 \%, * *$ Significant at 5\%, ** Significant at $1 \%$; 4 . For all OLS models refer to Table A3.

Table 2, Column 3 added temperature as a control variable, which showed that controlling the temperature did not substantively affect the precipitation estimates. Column 4 then added population growth as a control variable with the results again showing that controlling population growth did not affect the precipitation estimates and also did not affect the interaction term between precipitation and poor dummy province with the poor coefficient remaining unchanged. This evidence suggested that poorer regions were the locus of substantial positive precipitation effects. All the results were robust since temperature and population growth were used as the control variables, which did not affect precipitation, and when considering the coefficient, it did not change across all the models. Finally, when comparing Columns 4 and 5, using different estimators, the results of the coefficient remained unchanged and the standard error (SE) of the FGLS estimator was less than the OLS (Ordinary Least Squares) estimator with a fixed effect at all specifications. This evidence showed that the FGLS estimation could solve the heteroscedasticity problem as well as had a lower SE than the OLS estimation, thus resulting in reliable results.

The results of the point estimates in Table 2 for the overall models showed higher precipitation had reduced GPP growth rate, and a robust negative effect between average precipitation and GPP per capita growth in Thailand. By contrast, precipitation stimulated strong significant economic growth in poor provinces while temperature had a negative impact although this result was not statistically significant.

\subsection{Economic Sector Results}

Table 3 examines how precipitation affects the GPP per capita growth at the sector level (agriculture, industry, and service). Precipitation was found to have significant negative effects on the agricultural and service sectors while the industrial sector was positively affected by precipitation although this was not statistically significant. For the overall economic sector, temperature and population growth were conducted as the control variable. We found that the relationship between average precipitation and GPP growth was very robust since the precipitation coefficient remained unchanged across all 
panels (Column 4). In considering the economic sector and subsector, the present study had three interesting findings as follows.

Table 3. Economic sector panel results. Sample: 76 provinces (1995-2015); Estimation method: FGLS.

\begin{tabular}{|c|c|c|c|c|}
\hline & (1) & (2) & (3) & (4) \\
\hline \multicolumn{5}{|c|}{ Panel A. Dependent variable is growth in agriculture value added } \\
\hline Precipitation (100 mm/year) & $\begin{array}{c}-0.0316 \text { ** } \\
(0.0109)\end{array}$ & $\begin{array}{c}-0.0581 \text { *** } \\
(0.0131)\end{array}$ & $\begin{array}{c}-0.0584^{* * *} \\
(0.0133)\end{array}$ & $\begin{array}{c}-0.0586^{* * *} \\
(0.0133)\end{array}$ \\
\hline \multicolumn{5}{|l|}{ Precipitation interact with ... } \\
\hline Poor province dummy & & $\begin{array}{c}0.0754^{* * *} \\
(0.0209)\end{array}$ & $\begin{array}{c}0.0745^{* * *} \\
(0.0215)\end{array}$ & $\begin{array}{c}0.0745^{* * *} \\
(0.0215)\end{array}$ \\
\hline Temperature (Celsius) & & & $\begin{array}{c}-0.00458 \\
(0.0124)\end{array}$ & $\begin{array}{c}-0.00492 \\
(0.0124)\end{array}$ \\
\hline \multicolumn{5}{|l|}{ Temperature interact with ... } \\
\hline Poor province dummy & & & $\begin{array}{c}-0.00236 \\
(0.0121)\end{array}$ & $\begin{array}{c}-0.00196 \\
(0.0121)\end{array}$ \\
\hline Population growth & & & & $\begin{array}{c}-0.227 \\
(0.3221)\end{array}$ \\
\hline Constant & $\begin{array}{c}0.127 * * * \\
(0.0288)\end{array}$ & $\begin{array}{l}-0.0267 \\
(0.0296)\end{array}$ & $\begin{array}{c}0.196 \\
(0.1908)\end{array}$ & $\begin{array}{c}0.219 \\
(0.1846)\end{array}$ \\
\hline Observations & 1596 & 1596 & 1596 & 1596 \\
\hline Log likelihood & 1357.996 & 1364.506 & 1365.031 & 1365.279 \\
\hline \multicolumn{5}{|c|}{ Panel B. Dependent variable is growth in industrial value added } \\
\hline Precipitation (100 mm/year) & $\begin{array}{c}0.0212 \\
(0.0130)\end{array}$ & $\begin{array}{l}0.00975 \\
(0.0157)\end{array}$ & $\begin{array}{c}0.0134 \\
(0.0159)\end{array}$ & $\begin{array}{c}0.0132 \\
(0.0159)\end{array}$ \\
\hline \multicolumn{5}{|l|}{ Precipitation interact with ... } \\
\hline Poor province dummy & & $\begin{array}{c}0.0325 \\
(0.0250)\end{array}$ & $\begin{array}{c}0.0262 \\
(0.0258)\end{array}$ & $\begin{array}{c}0.0262 \\
(0.0258)\end{array}$ \\
\hline Temperature (Celsius) & & & $\begin{array}{c}0.0196 \\
(0.0148)\end{array}$ & $\begin{array}{c}0.0193 \\
(0.0148)\end{array}$ \\
\hline \multicolumn{5}{|l|}{ Temperature interact with ... } \\
\hline Poor province dummy & & & $\begin{array}{l}-0.0143 \\
(0.0145)\end{array}$ & $\begin{array}{l}-0.0140 \\
(0.0145)\end{array}$ \\
\hline Population growth & & & & $\begin{array}{c}-0.163 \\
(0.3855)\end{array}$ \\
\hline Constant & $\begin{array}{c}-0.105^{* * * *} \\
(0.0314)\end{array}$ & $\begin{array}{c}-0.126^{* * *} \\
(0.0354)\end{array}$ & $\begin{array}{c}-0.369 \\
(0.2284)\end{array}$ & $\begin{array}{l}-0.0821 \\
(0.2210)\end{array}$ \\
\hline Observations & 1596 & 1596 & 1596 & 1596 \\
\hline Log likelihood & 1090.343 & 1091.191 & 1092.098 & 1092.187 \\
\hline \multicolumn{5}{|c|}{ Panel C. Dependent variable is growth in service value added } \\
\hline Precipitation (100 mm/year) & $\begin{array}{c}-0.0132 \\
(0.0057)\end{array}$ & $\begin{array}{c}-0.0173 \text { * } \\
(0.0069)\end{array}$ & $\begin{array}{c}-0.0166^{*} \\
(0.0070)\end{array}$ & $\begin{array}{c}-0.0169 * \\
(0.0070)\end{array}$ \\
\hline \multicolumn{5}{|l|}{ Precipitation interact with ... } \\
\hline Poor province dummy & & $\begin{array}{c}0.0119 \\
(0.0110)\end{array}$ & $\begin{array}{c}0.0107 \\
(0.0114)\end{array}$ & $\begin{array}{c}0.0107 \\
(0.0113)\end{array}$ \\
\hline Temperature (Celsius) & & & $\begin{array}{l}0.00444 \\
(0.0065)\end{array}$ & $\begin{array}{l}0.00365 \\
(0.0065)\end{array}$ \\
\hline \multicolumn{5}{|l|}{ Temperature interact with ... } \\
\hline Poor province dummy & & & $\begin{array}{c}-0.00259 \\
(0.0064)\end{array}$ & $\begin{array}{c}-0.00163 \\
(0.0064)\end{array}$ \\
\hline Population growth & & & & $\begin{array}{c}-0.547^{* *} \\
(0.1694)\end{array}$ \\
\hline Constant & $\begin{array}{c}0.0546^{* * *} \\
(0.0151)\end{array}$ & $\begin{array}{c}0.0462 * * \\
(0.0170)\end{array}$ & $\begin{array}{l}-0.0546 \\
(0.1007)\end{array}$ & $\begin{array}{c}0.0168 \\
(0.0971)\end{array}$ \\
\hline Observations & 1596 & 1596 & 1596 & 1596 \\
\hline Log likelihood & 2335.928 & 2336.511 & 2336.795 & 2341.986 \\
\hline
\end{tabular}

Notes: 1. Standard errors in parentheses; 2 . Time and provincial fixed effects were included (coefficient not reported); 3. ${ }^{*}$ Significant at $10 \%, * *$ Significant at $5 \%,{ }^{* * *}$ Significant at $1 \%$; 4 . Industry classifications (refer to Table A4).

Firstly, it was surprising to find that precipitation had a negative effect on the agricultural sector although it remained positive for poorer regions (refer to Table 3, Panel A). Thailand's main agricultural products come from the country's poorer regions (the Northeast and North), which are very dry areas. 
Other agricultural products come from the South, which receives the highest volume of rainfall and is a large area covering 14 provinces. A potential explanation for why rainfall has a negative impact on the agricultural sector is that heavy rain events during the growing season may ruin agricultural products. During the rainy season, Thailand has also suffered from floods every year from 1986 to 2015 (The National Statistical Office of Thailand 2018). Very heavy rainfall can result in flooding, which can destroy agricultural products. Additionally, precipitation has a major role in the Thai agricultural sector since approximately 10,000 ha of the country's 13,100 ha of farming area is located away from irrigated areas (Bank of Thailand 2006). This means that $80 \%$ of the country's farmland is dependent on rainfall making Thai crop yields particularly sensitive to rainfall.

The present research also studied farming ${ }^{1}$ and fishing as agricultural subsectors, with both found to be negatively affected by precipitation although this was not significant for fishing (refer to Table 4). However, Thailand's northern and northeastern regions benefit from such precipitation. Considering the interaction between precipitation and the poor dummy province, the results showed that precipitation stimulated the agricultural sector in both of these poorer regions at the sector level (refer to Table 3, Panel A) and the subsector level (refer to Table 4, Column 1). This is because most farming income is generated from these poorer regions, which are also rather dry. This finding was consistent with previous studies, which found that rainfall had positive impacts on the economic growth of poor and arid countries that were reliant on rainfed agriculture (Abidoye and Odusola 2015; Ali 2012; Lanzafame 2014; Miguel and Satyanath 2011; Sequeira et al. 2018). In addition, the Mekong River is a major source of water for both northern and northeastern regions. Nevertheless, in 2010, both regions suffered the worst drought in 20 years due to the Mekong River falling to its lowest level for 50 years (Marks 2011). This evidence supports the assertion that rainfall is highly beneficial to Thailand's poorer regions due to their limited water supplies.

Table 4. Economic subsector results. Sample: 76 provinces (1995-2015); Estimation method: FGLS.

\begin{tabular}{|c|c|c|c|c|c|}
\hline & \multicolumn{5}{|c|}{ Dependent Variable } \\
\hline & \multirow{2}{*}{$\begin{array}{c}\text { Agriculture } \\
\mathbf{( 1 )} \\
\text { Farming } \\
\text { Growth }\end{array}$} & \multirow{2}{*}{$\begin{array}{c}\text { Industry } \\
(2) \\
\text { Mining } \\
\text { Growth }\end{array}$} & \multicolumn{3}{|c|}{ Services } \\
\hline & & & $\begin{array}{c}\text { (3) } \\
\text { Hotel } \\
\text { Growth }\end{array}$ & $\begin{array}{c}\text { (4) } \\
\text { Public } \\
\text { Growth }\end{array}$ & $\begin{array}{c}\text { (5) } \\
\text { Health } \\
\text { Growth }\end{array}$ \\
\hline Precipitation (100 mm/year) & $\begin{array}{c}-0.0609 * * * * \\
(0.0133)\end{array}$ & $\begin{array}{c}0.0997 * * \\
(0.0474)\end{array}$ & $\begin{array}{c}0.0620 * * \\
(0.0277)\end{array}$ & $\begin{array}{c}-0.0725^{* * *} \\
(0.0156)\end{array}$ & $\begin{array}{c}-0.0284 \text { * } \\
(0.0148)\end{array}$ \\
\hline Precipitation interact with ... & & & & & \\
\hline Poor province dummy & $\begin{array}{c}0.0610^{* * *} \\
(0.0215)\end{array}$ & $\begin{array}{l}-0.0573 \\
(0.0762)\end{array}$ & $\begin{array}{c}-0.120^{* * *} \\
(0.0447)\end{array}$ & $\begin{array}{c}0.0469 \\
(0.0253)\end{array}$ & $\begin{array}{l}0.00800 \\
(0.0238)\end{array}$ \\
\hline Temperature (Celsius) & $\begin{array}{l}-0.0129 \\
(0.0123)\end{array}$ & $\begin{array}{c}0.0345 \\
(0.0441)\end{array}$ & $\begin{array}{c}0.0680 * * * \\
(0.0257)\end{array}$ & $\begin{array}{l}-0.0173 \\
(0.0145)\end{array}$ & $\begin{array}{l}-0.0136 \\
(0.0137)\end{array}$ \\
\hline Temperature interact with ... & & & & & \\
\hline Poor province dummy & $\begin{array}{l}0.00665 \\
(0.0121)\end{array}$ & $\begin{array}{l}-0.0525 \\
(0.0432)\end{array}$ & $\begin{array}{c}-0.0646^{* *} \\
(0.0251)\end{array}$ & $\begin{array}{c}0.0252 \\
(0.0142)\end{array}$ & $\begin{array}{c}0.0153 \\
(0.0134)\end{array}$ \\
\hline Population growth & $\begin{array}{c}-0.604 \\
(0.3216)\end{array}$ & $\begin{array}{c}-1.925 \\
(1.1448)\end{array}$ & $\begin{array}{c}-0.721 \\
(0.6690)\end{array}$ & $\begin{array}{c}-0.132 \\
(0.3781)\end{array}$ & $\begin{array}{c}-1.083^{* * *} \\
(0.3568)\end{array}$ \\
\hline Constant & $\begin{array}{c}0.237 \\
(0.1843)\end{array}$ & $\begin{array}{c}0.605 \\
(0.6467)\end{array}$ & $\begin{array}{c}0.0630 \\
(0.3836)\end{array}$ & $\begin{array}{c}-0.128 \\
(0.2167)\end{array}$ & $\begin{array}{c}0.127 \\
(0.2045)\end{array}$ \\
\hline Observations & 1596 & 1596 & 1596 & 1596 & 1596 \\
\hline Log likelihood & 1367.865 & -500.816 & 253.853 & 1121.597 & 1209.817 \\
\hline
\end{tabular}

1 Farming is defined as agriculture, hunting and forestry (refer to Table A4). 
Secondly, precipitation was found not to impact the industry sector (refer to Table 3, Panel B) although when considering the four industry subsectors, only the mining subsector was positively influenced by precipitation. The evidence showed that a $100 \mathrm{~mm}$ rise in precipitation was to increase the mining growth rate by $9.97 \%$ (refer to Table 4, Column 2). Our hypothesis was that certain mining activities used rainwater during the production process; such as, during salt extraction.

Thirdly, rainfall was found to have a negative impact on the service sector (refer to Table 3, Panel C) although certain subsectors of service were stimulated by precipitation. Ten subsectors were considered in total. This study found that three subsectors were influenced by precipitation: hotels and restaurants; public administration, and health and social work (refer to Table 4, Columns 3-5). The results showed that hotels and restaurants positively benefitted from precipitation while precipitation had a significantly negative effect on poor provinces in this sector since the population received a low income lacking the purchasing power to interact with hotels and restaurants. A potential explanation for why precipitation is beneficial to hotels and restaurants is that this subsector is part of the tourism industry ${ }^{2}$ (World Travel and Tourism Council 2018). Most of Thailand's tourism income comes from the South, which is near the sea. Furthermore, many tourist activities can be stimulated during the rainy season; such as, hiking, visiting waterfalls, rafting, etc. These activities in particular are more popular when the water level rises, so they attract more tourists to enjoy the abundance of the forests and nature during the rainy season. Thus, recreational activities during the rainy season may encourage hotel and restaurant activities. Finally, there are two subsectors that have been negatively affected by precipitation, which are public administration and defence, and health. There may also be an overabundance between different subsectors. For instance, if farming income falls, agricultural workers may reduce their demand for other goods, which would affect other subsectors; such as, health (refer to Table 4, Columns 1 and 5). This evidence was consistent with the economy in the poor areas of Thailand, which are the northeastern and northern regions, since most income in these regions comes from the agricultural and health subsectors. Hence, these two subsectors have more opportunity to easily have an overabundance, particularly in the poor areas of Thailand. In case of public administration and defence, precipitation may be an obstacle to commute, as most activities are outdoor events; such as, provision of services to the community (refer to the definition of economic activities in Table A4).

\section{Conclusions}

This study investigated how rainfall affected Thailand's economic growth. The study found that rainfall has had a substantially negative impact on economic growth at the provincial level while temperature was not found to have a significant effect. The estimate further suggested that rainfall was the key climatic factor influencing the historical GPP growth in Thailand. Additionally, precipitation had a significant negative effect on the agriculture and service sectors although it was beneficial for the agriculture sector in Thailand's poorer regions. Furthermore, the research found that agriculture was the most vulnerable sector to rainfall followed by the service sector. Moreover, rainfall had a positive impact on the industry sector although this was not significant. Finally, we investigated the subsectors of the previously mentioned economic activities with the results finding that rainfall stimulated mining and hotels and restaurants while negatively affecting the agricultural, public administration and defence, and health subsectors.

In conclusion, the evidence showed that rainfall was the key climatic variable in Thailand within the field of climate change, which contrasted with previous research that had suggested that temperature was the key climatic variable (Dell et al. 2008; 2012; Lanzafame 2014). Similar to other tropical countries, rainfall changes affect Thailand's productivity with the exception of the poorer

2 The tourism industry consists of (1) accommodation services; (2) food and beverage services; (3) retail trade; (4) transportation services, and (5) cultural sports and recreation. 
regions in which rainfall remains economically beneficial. This finding could help to determine which economic sectors were most needed, and which areas were vulnerable to rainfall stresses. Overall, the results showed that rainfall had a mostly negative impact on Thailand's economic activities with the exception of the mining and hotel and restaurant subsectors. Future research should concentrate on studying each activity in depth; such as, how precipitation affects the mining industry. A detailed understanding of the economic activities that are impacted by climatic factors could lead to the implementation of more effective government decisions.

Author Contributions: The paper is a joint contribution of the two authors. All authors have read and agreed to the published version of the manuscript.

Funding: This research received no external funding.

Acknowledgments: We are grateful to the two anonymous reviewers for excellent comments on an earlier draft and thank you very much for the three anonymous referees on the present study.

Conflicts of Interest: The authors declare no conflicts of interest.

\section{Appendix A}

\section{Appendix A.1. Panel Unit Root Test}

The panel unit root test was used to determine whether the variables were stationary or non-stationary at the same level. To achieve such a possibility, they apply the principal component method to the first-differenced version of the model and estimate the factor loadings and the first differences of the common factors (Pesaran 2007). These so-called 'second generation' panel unit root tests are examined in Breitung and Pesaran (Breitung and Pesaran 2008) and (Choi 2006).

Table A1. Cross-sectionally augmented Im-Pesaran-Shin (CIPS) panel unit root test.

\begin{tabular}{|c|c|c|c|c|}
\hline \multirow{2}{*}{ Series Name } & \multicolumn{2}{|c|}{ No Trend } & \multicolumn{2}{|c|}{ Trend } \\
\hline & Statistic & $p$ Value & Statistic & $p$ Value \\
\hline \multicolumn{5}{|l|}{ Dependent variable } \\
\hline \multicolumn{5}{|l|}{ National level } \\
\hline GPP per capita growth & $-22.104^{* * *}$ & 0.000 & $-18.824^{* * *}$ & 0.000 \\
\hline Sector level & & & & \\
\hline Agriculture & $-21.961^{* * *}$ & 0.000 & $-18.505^{* * *}$ & 0.000 \\
\hline Agriculture value added per capita growth & & & & \\
\hline $\begin{array}{l}\text { Industrial } \\
\text { Industrial value added per capita growth }\end{array}$ & $-22.615^{* * *}$ & 0.000 & $-19.00 * * *$ & 0.000 \\
\hline $\begin{array}{l}\text { Service } \\
\text { Service value added per capita growth }\end{array}$ & $-21.813^{* * *}$ & 0.000 & $-18.883^{* * *}$ & 0.000 \\
\hline \multicolumn{5}{|l|}{ Subsector level } \\
\hline $\begin{array}{l}\text { Farming } \\
\text { Farming value added per capita growth }\end{array}$ & $-22.747^{* * *}$ & 0.000 & $-18.740 * * *$ & 0.000 \\
\hline $\begin{array}{l}\text { Mining } \\
\text { Mining value added per capita growth }\end{array}$ & $-20.454^{* * *}$ & 0.000 & $-16.966^{* * *}$ & 0.000 \\
\hline $\begin{array}{l}\text { Hotel } \\
\quad \text { Hotel value added per capita growth }\end{array}$ & $-17.739 * * *$ & 0.000 & $-15.055^{* * *}$ & 0.000 \\
\hline $\begin{array}{l}\text { Public } \\
\quad \text { Public value added per capita growth }\end{array}$ & $-18.620^{* * *}$ & 0.000 & $-15.055^{* * *}$ & 0.000 \\
\hline $\begin{array}{l}\text { Health } \\
\text { Health value added per capita growth }\end{array}$ & $-29.856^{* * *}$ & 0.000 & $-26.647^{* * *}$ & 0.000 \\
\hline \multicolumn{5}{|l|}{ Independent variable } \\
\hline $\begin{array}{l}\text { Rain } \\
\text { Annual average rainfall }(\mathrm{mm})\end{array}$ & $-21.383^{* * *}$ & 0.000 & $-19.133^{* * *}$ & 0.000 \\
\hline $\begin{array}{l}\text { Temperature } \\
\text { Annual average temperature }\left({ }^{\circ} \mathrm{C}\right)\end{array}$ & $-5.190^{* * *}$ & 0.000 & $-6.888^{* * *}$ & 0.000 \\
\hline $\begin{array}{l}\text { Population growth } \\
\text { Population growth rate }\end{array}$ & $-12.212^{* * *}$ & 0.000 & $-8.514^{* * *}$ & 0.000 \\
\hline
\end{tabular}

Note: The test null hypothesis is non-stationarity of the series; Level of significance: ${ }^{* * *}$ for $p$ value $<0.01$; ${ }^{* *}$ for $p$ value $<0.05 ;{ }^{*}$ for $p$ value $<0.1$. 
Appendix A.2. Panel Heteroskedasticity Test

Heteroskedasticity refers to the situation in which the variance of the error term is not constant. James and Mark (Stock and Watson 2011) indicated that if the regression error is heteroskedastic, standard errors are not a reliable basis for hypothesis tests and confidence intervals, while Wooldridge (2015) stated that if regression disturbances are homoskedastic with the same variance across time and individuals, then this may be a restrictive assumption for panels.

Table A2. Breusch-Pagan/Cook-Weisberg test for heteroskedasticity.

\begin{tabular}{ccc}
\hline Model & $\chi^{2}$-statistic & prob $-\chi^{2}$ \\
\hline Main panel & 3.66 & 0.0556 \\
Industrial sectors & & \\
Agriculture & 25.87 & 0.0000 \\
Industry & 2.99 & 0.0840 \\
Service & 4.03 & 0.0447 \\
Farming & 52.90 & 0.0000 \\
Mining & 15.33 & 0.0001 \\
Hotel & 0.93 & 0.3359 \\
Public & 44.52 & 0.0000 \\
Health & 320 & 0.0000 \\
\hline
\end{tabular}

Note: The heteroskedasticity test with all models.

Table A3. Main economic growth results. Sample: 76 provinces (1995-2015); Estimation method: Ordinary Least Squares (OLS).

\begin{tabular}{|c|c|c|c|c|}
\hline $\begin{array}{l}\text { Dependent Variable Is } \\
\text { the Annual Growth Rate }\end{array}$ & (1) & (2) & (3) & (4) \\
\hline Precipitation (100 mm/year) & $\begin{array}{c}-0.0120 * \\
(0.0067)\end{array}$ & $\begin{array}{c}-0.0238^{* * *} \\
(0.0088)\end{array}$ & $\begin{array}{c}-0.0231^{* *} \\
(0.0090)\end{array}$ & $\begin{array}{c}-0.0234^{\text {** }} \\
(0.0090)\end{array}$ \\
\hline \multicolumn{5}{|l|}{ Precipitation interact with ... } \\
\hline Poor province dummy & & $\begin{array}{c}0.0337 * * * \\
(0.0127)\end{array}$ & $\begin{array}{c}0.0322 * * \\
(0.0130)\end{array}$ & $\begin{array}{c}0.0322 * * \\
(0.0130)\end{array}$ \\
\hline Temperature (Celsius) & & & $\begin{array}{l}0.00383 \\
(0.0081)\end{array}$ & $\begin{array}{l}0.00321 \\
(0.0081)\end{array}$ \\
\hline \multicolumn{5}{|l|}{ Temperature interact with ... } \\
\hline Poor province dummy & & & $\begin{array}{c}-0.00321 \\
(0.0079)\end{array}$ & $\begin{array}{c}-0.00247 \\
(0.0079)\end{array}$ \\
\hline Population growth & & & & $\begin{array}{c}-0.421^{* *} \\
(0.2109)\end{array}$ \\
\hline Constant & $\begin{array}{c}0.0801^{* * * * *} \\
(0.0128)\end{array}$ & $\begin{array}{c}0.0576^{* * * * *} \\
(0.0146)\end{array}$ & $\begin{array}{c}0.0425 \\
(0.0776)\end{array}$ & $\begin{array}{c}0.0443 \\
(0.0778)\end{array}$ \\
\hline Observations & 1596 & 1596 & 1596 & 1596 \\
\hline$R^{2}$ & 0.2643 & 0.2680 & 0.2682 & 0.2706 \\
\hline
\end{tabular}

Notes: 1. Robust standard errors in parentheses. 2. Time and provincial fixed effects were included (coefficient not reported). $3 .{ }^{*}$ Significant at $10 \%,{ }^{* *}$ Significant at $5 \%, * * *$ Significant at $1 \%,{ }^{* * * *}$ Significant at $0.1 \%$. 


\section{Appendix B}

Table A4. Economic activities classification and definition.

\begin{tabular}{|c|c|c|}
\hline $\begin{array}{l}\text { Economic } \\
\text { Sector }\end{array}$ & Economic Activities & Definition \\
\hline & Agriculture & \\
\hline Agriculture & 1. Agriculture, hunting and forestry & $\begin{array}{l}\text { Division } 01 \text { Agriculture, hunting and related service activities } \\
\text { Division } 02 \text { Forestry, logging and related service activities }\end{array}$ \\
\hline \multirow[t]{2}{*}{ Agriculture } & 2. Fishing & $\begin{array}{l}\text { Division } 05 \text { Fishing, operation of fish hatcheries and fish farms; } \\
\text { service activities incidental to fishing }\end{array}$ \\
\hline & Non-Agriculture & \\
\hline Industry & 3. Mining and quarrying & $\begin{array}{l}\text { Division } 10 \text { Mining of coal and lignite; extraction of peat } \\
\text { Division } 11 \text { Extraction of crude petroleum and natural } \\
\text { Gas; service activities incidental to oil and gas } \\
\text { Extraction excluding surveying } \\
\text { Division } 12 \text { Mining of uranium and thorium ores } \\
\text { Division } 13 \text { Mining of metal ores } \\
\text { Division } 14 \text { Other mining and quarrying }\end{array}$ \\
\hline Industry & 4. Manufacturing * & \\
\hline Industry & 5. Electricity, Gas and Water supply * & \\
\hline Industry & 6. Construction * & \\
\hline Service & $\begin{array}{l}\text { 7. Wholesale and retail trade; repair of } \\
\text { motor vehicles, motorcycles and personal } \\
\text { and household goods* }\end{array}$ & \\
\hline Service & 8. Hotels and restaurants & $\begin{array}{l}\text { Division } 55 \text { Hotels and restaurants } \\
551 \text { Hotels; camping sites and other provision of short } \\
\text { stay accommodation } \\
552 \text { Restaurants, bars and canteens }\end{array}$ \\
\hline Service & $\begin{array}{l}\text { 9. Transport, storage } \\
\text { and communications * }\end{array}$ & \\
\hline Service & 10. Financial intermediation * & \\
\hline Service & $\begin{array}{l}\text { 11. Real estate, renting and } \\
\text { business activities * }\end{array}$ & \\
\hline Service & $\begin{array}{l}\text { 12. Public administration and defence; } \\
\text { compulsory social security }\end{array}$ & $\begin{array}{l}\text { Division } 75 \text { Public administration and defence; compulsory } \\
\text { social security } \\
751 \text { Administration of the State and the economic and social } \\
\text { policy of the community } \\
752 \text { Provision of services to the community as a whole } \\
753 \text { Compulsory social security activities }\end{array}$ \\
\hline Service & 13. Education* & \\
\hline Service & 14. Health and social work & $\begin{array}{l}\text { Division } 85 \text { Health and Social Work } \\
851 \text { Human health activities } \\
852 \text { Veterinary activities } \\
853 \text { Social work activities }\end{array}$ \\
\hline Service & $\begin{array}{l}\text { 15. Other community, social and personal } \\
\text { service activities * }\end{array}$ & \\
\hline Service & $\begin{array}{l}\text { 16. Private households with } \\
\text { employed persons* }\end{array}$ & \\
\hline
\end{tabular}

Source: Economic activities classification; Office of the National Economic and Social Development Board of Thailand (2015). Note: * All these activities are not significant and more definition information refer to International Standard Classification of Industry (ISCI) Revision 3 (United Nations Statistics Division 1986).

\section{References}

Abidoye, Babatunde O., and Ayodele F. Odusola. 2015. Climate Change and Economic Growth in Africa: An Econometric Analysis. Journal of African Economies 24: 277-301. [CrossRef]

Akram, Naeem. 2012. Is climate change hindering economic growth of Asian economies. Asia-Pacific Development Journal 19: 1-18. [CrossRef] 
Alagidede, Paul, George Adu, and Prince Boakye Frimpong. 2015. The effect of climate change on economic growth: evidence from Sub-Saharan Africa. Environmental Economics and Policy Studies 18: 417-36. [CrossRef]

Ali, Seid. 2012. Climate Change and Economic Growth in a Rain-Fed Economy: How Much Does Rainfall Variability Cost Ethiopia? EEA Working Paper Series, Ethiopia Ethiopian Economics Association, Addis Ababa, Ethiopia.

Angrist, Joshua D., and Alan B. Krueger. 2001. Instrumental variables and the search for identification: From supply and demand to natural experiments. Journal of Economic Perspectives 15: 69-85. [CrossRef]

Auffhammer, Maximilian, Solomon M. Hsiang, Wolfram Schlenker, and Adam Sobel. 2013. Using Weather Data and Climate Model Output in Economic Analyses of Climate Change. Review of Environmental Economics and Policy 7: 181-98. [CrossRef]

Bank of Thailand. 2006. Irrigation System for Thai Agriculture. Available online: https://www.bot.or.th/Thai/ MonetaryPolicy/Northern/DocLib_Article/ThailandIrrigationAgriSector.pdf (accessed on 19 July 2019).

Barrios, Salvador, Luisito Bertinelli, and Eric Strobl. 2010. Trends in rainfall and economic growth in Africa: A neglected cause of the African growth tragedy. The Review of Economics and Statistics 92: 350-66. [CrossRef]

Becken, Susanne, and Jude Wilson. 2013. The impacts of weather on tourist travel. Tourism Geographies 15: 620-39. [CrossRef]

Berlemann, Michael, and Daniela Wenzel. 2015. Long-Term Growth Effects of Natural Disasters-Empirical Evidence for Droughts. CESifo Working Paper No. 5598, CESifo Center for Economic Studies \& Ifo Institute, Munich, Germany.

Berlemann, Michael, and Daniela Wenzel. 2018. Precipitation and Economic Growth. CESifo Working Paper No. 7258, Munich Society for the Promotion of Economic Research-CESifo GmbH, Munich, Germany.

Borgomeo, Edoardo, Bryan Vadheim, Firew B. Woldeyes, Tena Alamirew, Seneshaw Tamru, Katrina J. Charles, Seifu Kebede, and Oliver Walker. 2018. The Distributional and Multi-Sectoral Impacts of Rainfall Shocks: Evidence from Computable General Equilibrium Modelling for the Awash Basin, Ethiopia. Ecological Economics 146: 621-32. [CrossRef]

Breitung, Jörg, and M. Hashem Pesaran. 2008. Unit roots and cointegration in panels. In The Econometrics of Panel Data. Berlin: Springer, pp. 279-322.

Brown, Casey, Robyn Meeks, Kenneth Hunu, and Winston Yu. 2011. Hydroclimate risk to economic growth in sub-Saharan Africa. Climatic Change 106: 621-47. [CrossRef]

Brown, Casey, Robyn Meeks, Yonas Ghile, and Kenneth Hunu. 2013. Is water security necessary? An empirical analysis of the effects of climate hazards on national-level economic growth. Philosophical Transactions of the Royal Society A 371. [CrossRef]

Burke, Paul J, and Andrew Leigh. 2010. Do output contractions trigger democratic change? American Economic Journal: Macroeconomics 2: 124-57. [CrossRef]

Cabral, François Joseph. 2014. Rainfall and Economic Growth and Poverty: Evidence from Senegal and Burkina Faso. Washington, DC: African Growth \& Development Policy (AGRODEP) Modeling Consortium.

Carleton, Tamma A., and Solomon M. Hsiang. 2016. Social and economic impacts of climate. Science 353: aad9837. [CrossRef] [PubMed]

Choi, In. 2006. Nonstationary Panels. In Palgrave Handbooks of Econometrics. New York: Palgrave Macmillan, vol. 1, pp. 511-39.

Dell, Melissa, Benjamin F. Jones, and Benjamin A. Olken. 2008. Climate Change and Economic Growth: Evidence from the Last Half Century. Cambridge: National Bureau of Economic Research.

Dell, Melissa, Benjamin F. Jones, and Benjamin A. Olken. 2009. Temperature and income: reconciling new cross-sectional and panel estimates. American Economic Review 99: 198-204. [CrossRef]

Dell, Melissa, Benjamin F. Jones, and Benjamin A. Olken. 2012. Temperature shocks and economic growth: Evidence from the last half century. American Economic Journal: Macroeconomics 4: 66-95. [CrossRef]

Dell, Melissa, Benjamin F. Jones, and Benjamin A. Olken. 2014. What Do We Learn from the Weather? The New Climate-Economy Literaturet. Journal of Economic Literature 52: 740-98. [CrossRef]

Department of Provincial Administration. 2018. Population at the Provincial Level Report. Bangkok: The Ministry of Interior.

Dore, Mohammed H. I. 2005. Climate change and changes in global precipitation patterns: What do we know? Environment International 31: 1167-81. [CrossRef] [PubMed]

Fankhauser, Samuel, and Richard S. J. Tol. 2005. On climate change and economic growth. Resource and Energy Economics 27: 1-17. [CrossRef] 
Gadgil, Sulochana, and Siddhartha Gadgil. 2006. The Indian Monsoon, GDP and Agriculture. Economic and Political Weekly 41: 4887-95.

Gallup, John Luke, Jeffrey D. Sachs, and Andrew D. Mellinger. 1999. Geography and economic development. International Regional Science Review 22: 179-232. [CrossRef]

Gates, Warren E. 1967. The spread of Ibn Khaldun's ideas on climate and culture. Journal of the History of Ideas 28: 415. [CrossRef]

Gilmont, M., J. W. Hall, D. Grey, S. J. Dadson, S. Abele, and M. Simpson. 2018. Analysis of the relationship between rainfall and economic growth in Indian states. Global Environmental Change 49: 56-72. [CrossRef]

Henseler, Martin, and Ingmar Schumacher. 2019. The impact of weather on economic growth and its production factors. Climatic Change 154: 417-33. [CrossRef]

Hissler, Sebastien. 2010. Econometric Study on the Impact of Rainfall Variability on Security in the Sahel Region. Brussels: Organization of Economic Cooperation and Development \& Sahel and West Africa Club Secretariat.

Horowitz, John K. 2009. The income-temperature relationship in a cross-section of countries and its implications for predicting the effects of global warming. Environmental and Resource Economics 44: 475-93. [CrossRef]

Jones, Benjamin F., and Benjamin A. Olken. 2010. Climate shocks and exports. American Economic Review 100: 454-59. [CrossRef]

Lanzafame, Matteo. 2014. Temperature, rainfall and economic growth in Africa. Empirical Economics 46: 1-18. [CrossRef]

Lertamphainont, Sirikarn, and Robert Sparrow. 2016. The Economic Impacts of Extreme Rainfall Events on Farming Households: Evidence from Thailand. PIER Discussion Papers No. 45. Bangkok: Puey Ungphakorn Institute for Economic Research.

Loayza, Norman V, Eduardo Olaberria, Jamele Rigolini, and Luc Christiaensen. 2012. Natural disasters and growth: Going beyond the averages. World Development 40: 1317-36. [CrossRef]

Mariani, Fabio, Agustin Pérez-Barahona, and Natacha Raffin. 2010. Life expectancy and the environment. Journal of Economic Dynamics and Control 34: 798-815. [CrossRef]

Marks, Danny. 2011. Climate Change and Thailand: Impact and Response. Contemporary Southeast Asia 33: 229. [CrossRef]

Miguel, Edward, and Shanker Satyanath. 2011. Re-examining economic shocks and civil conflict. American Economic Journal: Applied Economics 3: 228-32. [CrossRef]

Nordhaus, William D. 2010. Modeling induced innovation in climate-change policy. In Technological Change and the Environment. Abingdon: Routledge, pp. 188-215.

Odusola, Ayodele, and Babatunde Abidoye. 2015. Effects of Temperature and Rainfall Shocks on Economic Growth in Africa. Paper presented at the International Association of Agricultural Economists 29th Triennial Conference, Milan, Italy, August 8-14.

Office of the National Economic and Social Development Board of Thailand. 2015. Gross Regional and Provincial Product, Chain Volume Measures 2015 Edition. Bangkok: The Office of the Prime Minister.

Office of the National Economic and Social Development Board of Thailand. 2017. Gross Regional and Provincial Product Chain Volume Measures 2017 Edition. Bangkok: The Office of the Prime Minister.

Pesaran, M Hashem. 2007. A simple panel unit root test in the presence of cross-section dependence. Journal of Applied Econometrics 22: 265-312. [CrossRef]

Phatcharopaswatanagul, Apinan. 2018. Impacts of climate change on casava in Northeastern of Thailand. Ph.D. thesis, Maejo University, Chiang Mai, Thailand.

Richardson, Craig J. 2007. How much did droughts matter? Linking rainfall and GDP growth in Zimbabwe. African Affairs 106: 463-78. [CrossRef]

Sequeira, Tiago Neves, Marcelo Serra Santos, and Manuela Magalhães. 2018. Climate change and economic growth: A heterogeneous panel data approach. Environmental Science and Pollution Research 25: 22725-35. [CrossRef] [PubMed]

Solaun, Kepa, and Emilio Cerdá. 2017. The Impact of Climate Change on the Generation of Hydroelectric Power-A Case Study in Southern Spain. Energies 10: 1343. [CrossRef]

Stock, James H., and Mark W. Watson. 2011. Introduction to Econometrics. Boston: Pearson Education.

Tebaldi, Edinaldo, and Laura Beaudin. 2016. Climate change and economic growth in Brazil. Applied Economics Letters 23: 377-81. [CrossRef] 
Thai Meteorological Department. 2016. Annual Weather Summary of Thailand in 2011. Available online: http://www.tmd.go.th/programs\%5Cuploads\%5CyearlySummary\%5CAnnual2011_up.pdf (accessed on 19 July 2019).

The Intergovernmental Panel on Climate Change (IPCC). 2007a. The physical science basis. In Contribution of Working Group I to the Fourth Assessment Report of the Intergovernmental Panel on Climate Change. Geneva: IPCC.

The Intergovernmental Panel on Climate Change (IPCC). 2007b. Climate Change 2007 The Physical Science Basis. Projections of Future Changes in Climate. Available online: http://www.ipcc.ch/publications_and_data/ar4/ wg1/en/spmsspm-projections-of.html (accessed on 19 July 2019).

The National Statistical Office of Thailand. 2018. Thailand Flooding in 1989-2017 Report; Bangkok: The Ministry of Digital Economy and Society.

United Nations Statistics Division. 1986. Standard International Trade Classification Revision 3. Series M: Miscellaneous Statistical Papers, No. 34 Rev. 3. New York: United Nations.

Wild, Sarah. 2015. FACTSHEET: Why Africa Is Vulnerable to Climate Change. Available online: https: //africacheck.org/factsheets/factsheet-why-africa-is-vulnerable-to-climate-change/ (accessed on 20 July 2019).

Wooldridge, Jeffrey M. 2015. Introductory Econometrics: A Modern Approach. Toronto: Nelson Education.

World Bank. 2011. Thailand Now an Upper Middle Income Economy. Available online: https://www. worldbank.org/en/news/press-release/2011/08/02/thailand-now-upper-middle-income-economy (accessed on 19 July 2019).

World Travel and Tourism Council. 2018. Available online: https://www.wttc.org/-/media/files/reports/economicimpact-research/countries-2018/thailand2018.pdf (accessed on 19 July 2019).

Zeb, Aurangzeb. 2013. Climate Change and Economic Growth in Nordic Countries: An application of smooth coefficient semi-parametric approach. International Journal of Social Sciences II: 159-71.

(C) 2019 by the authors. Licensee MDPI, Basel, Switzerland. This article is an open access article distributed under the terms and conditions of the Creative Commons Attribution (CC BY) license (http://creativecommons.org/licenses/by/4.0/). 